Dolya C.,

Botsman A., Kozhyna V.

\title{
INVESTIGATION OF APPROACHES TO MODELING OF INTERCITY PASSENGER TRANSPORTATION SYSTEM
}

\begin{abstract}
Досліджено стан сучасних наукових підходів до прогнозування параметрів міжміських паса-
\end{abstract} жирських кореспонденцій. Встановлено, що міжміські пасажирські транспортні кореспонденціі можна обрахувати використовуючи сучасні підходи, які базуються на принципі гравітаціного моделювання. В системі міжміських пасажирських маршрутних перевезень спостерігаються процеси розподілу пасажиропотоку між видами транспорту завдяки набору варіантів реалізацій потреби пасажирів на пересування.

Ключові слова: транспортна система, гравітачійна модель, пасажирські транспортні кореспонденцї, міжміські перевезення.

\section{Introduction}

The functioning of intercity passenger transportation system is satisfactory in the presence of stably satisfactory parameters of the functioning of this system. The main parameters of the functioning of passenger transport systems include: transportation regularity, waiting time, the cost of accessibility of the journey, the safety of the carriage and its comfort, the convenience of ticket and train services, the speed of the carriage, and so on. These efficiency parameters can be related to the product of the functioning of the transport system - movement.

Transport systems of intercity passenger route transportation operate in a multifactor environment, among which there are those that can change their influence on the transport system in time. Such factors include fluctuations in both the demand for movement and its monetary security.

The results of fluctuations influence on the transport system in the actual parameters of intercity passenger correspondence are reflected in the changes in traffic schedules and types of rolling stock. Due to the changes it is supported to comply with the requirements for meeting the requirements for the movement of passengers with the desired route parameters of the transport system and ensuring compliance with the overall performance of the system. Therefore, the study of the issue of an integrated approach to the modeling of passenger transport correspondence, taking into account certain parameters, is relevant.

\section{The object of research and its technological audit}

The object of research is the state (regional) transport system. This research examines the development of scientific approaches to the solution of the problem of forecasting the state of the passenger transport system parameters at the state or interregional level.

One of the most problematic places is the forecasting of quantitative parameters of the functioning environment of the transport route passenger system.

\section{The aim and objectives of research}

The aim of research is determination of certain regularities in the functioning of long-distance passenger transportation systems. Definition of the current state of the development of scientific approaches to the forecasting of intercity passenger correspondence, methods for ensuring the calculation of the provision of requirements for the movement of certain types of transport.

To achieve the aim, the following tasks are supposed to be solved:

1. To establish the scientific approaches proposed by contemporaries for the calculation of passenger correspondence between cities, taking into account their geographical calculation, social and economic indicators.

2. To define methods for predicting the distribution of correspondence between modes of transport.

\section{Research of existing solutions of the problem}

Modern scientific approaches to planning the parameters of transport systems determine methods that rely on the recording of passenger correspondence between the nodes of the transport network. The authors in [1] presented an approach to intelligent route planning in public transport systems. The approach focuses on formal modeling of the semi-dynamic intelligent planning and route optimization. To this end, it is important to have a well-developed formal model that covers both the space aspects in real time. The proposed solution allows developers to extend the public transport system with additional routes, which are created dynamically based on requests from passengers. The model can be used within a sustainable Smart City for (fully or partially) autonomous transport systems and decision support systems for smart transport systems. In work [2] vertical bus routes have been developed that reach the system of railway stations, as well as bus lines that link to the city center, turning into regional bus lines. The authors of [3] considered the 
problem of planning routes for public transport systems and suggested the representation of a multimodal transport network using the multi-criteria routing algorithm for modeling. In the authors' paper [4], a model of the probabilistic process of bus communication is defined. The authors of [5] determined that the choice of a route by a multitude of passengers plays a primary role in estimating flows and forecasting demand. In work [6] the issue of an establishment of transport service time depending on an arrangement of stopping points was considered. The authors [7] disclosed the issues of estimating the number of passengers carried by the public transport system, taking into account the behavioral model of people and their influence on the choice of the transportation mode. The authors of [8] determined the parameters for optimizing the transit railway route and the bus routes of the transit corridor. Research result is the definition of a multi-purpose model that maximizes rail transit passenger traffic and minimizes the total time of the passenger transit route.

The authors of [9] were engaged in the description of the method of solving one of the main problems in the transportation organization - the choice of an optimal route with an emphasis on the factor of road safety. New optimal approaches to solving the network approach are used in $[10,11]$. The authors in [12] integrated the side of the supply of public transport into the model of the traveler demand. The model also contains power limits for vehicles, which, when activated, lead to a significant increase in travel time. The following questions are disclosed in [13]:

- or it is expected that the total demand for long-distance travel by car and airplane will grow in the future in accordance with trends in population and income;

- enough income to achieve maximum dynamics of long-distance traffic per capita;

- or the growth of air transportation is due to traditional socio-economic factors (population and income growth).

In work [14], issues of improvement of railway transportation system were considered, and in work [15] the network was considered, which has various modes of transportation and multimodal systems of public transport. The proposed study of a flexible method for optimizing the timetable based on the model of a hybrid car size to solve the fluctuations of bus demand during transit operation was proposed by the authors in [16]. The study verifies the rationality of the hybrid model's vehicle size strategy and emphasizes the importance of an adaptive vehicle size in dealing with demand fluctuations.

The approach of modeling the demand for travel and its distribution in accordance with the volume restrictions at the zonal level, which are as compulsory as the limitation of the capacity of common references, are described by the authors in [17-19].

The authors of [20] dealt with the modeling of correspondence using gravitational models. In this paper, two gravitational models are presented for estimating the volume of passenger traffic between pairs of cities. Models contain variables that characterize the overall economic activity and geographical features of cities.

Both models are suitable for observable data, which are statistically verified and confirmed.

$$
H_{i j}=a \frac{\left(f_{i} f_{j}\right)^{F_{j}}}{\ell_{r}^{\ell_{r}}},
$$

where $H_{i j}$ - the volume of passenger traffic between cities $i$ and $j(i \neq j) ; f_{i}, f_{j}-$ attractiveness factors for cities $i$ and $j$; $l_{r}$ - total length of the route between the starting and ending points of the route; $a$ - an empirical constant; $\varphi_{t r}-$ coefficient of transport use; $p_{f}-$ parameter of attractiveness of factors for the trip.

$$
H_{i j}=e^{\varepsilon} P_{i j}^{\pi} Z_{i j}^{\chi} F_{Q}^{I} V V P_{i j}^{\gamma} l_{m}^{\delta} T_{t r}^{\tau},
$$

where $P_{i j}$ - the probability that the movement will start in region $i$ and end in region $j ; Z_{i}$ - service area; $F_{Q}$ - the purchasing power factor; $V V P_{i j}$ - the total domestic gross product of the city $i$ and $j ; T_{t r}$ - movement time of passengers in a vehicle; $\varepsilon, \pi, \chi, \beta, \gamma, \delta, \tau$ - empirical coefficients.

Both models use mainly geo-economic variables as independent factors.

In work [21] the issue of influence of actual indicators of long-distance passenger correspondence on development of transport infrastructure was considered. The authors of [22] proposed a simple technique for quantifying the parameters of the urban transport system, and the authors [23] analyzed the characteristics of urban rail and bus transport, based on this, a model was constructed for planning the area of paddle buses and an algorithm was proposed. The authors of [24] considered the effect of the population demand on displacement speed. Not without attention, scientists have left and the development of high-speed communication, which is set forth in [25].

In [26] they considered the planning of the route with the support of bus services and walking.

Modeling of predicting the parameters of the vehicle transport process in work $[27,28]$ is provided by the authors taking into account factors such as type of service, capacity limitations, methods of collecting the tariff for traffic, crowding in the car, and increasing the accuracy of forecasting the bus stop time. Consideration of changes in the performance indicators of passenger transport systems were described in [29-31].

The author of [32] determines that the main characteristic of the transport system is accessibility. The paper presents an approach to modeling regional accessibility of transit multimodal transport with an assessment of the Petri net modeling within the framework of the regional intellectual transport system with many specific aspects of analysis and accessibility modeling:

- multi-level structures of hierarchies;

- multifunctional objects of modeling;

- different types of traffic flow (passenger and cargo);

- heterogeneous components of modeling system.

The authors of [33] considered the issue of increasing mobility of the population. It is determined that the performance of public transport is limited not only by its availability, but also its capacity. Actual, the capacity of the transport line is determined by the operating frequency, as well as by the physical capabilities of each vehicle. The interrelationship between the loaded demand and capacity contributes to the establishment of comfort levels, including the quality of service in general. Modeling these phenomena in the destination model, which describes the user of the route and the mode of choice, transportation of supplies must be subject to a number of limitations: vehicle power (sitting and standing seats), landing and disembarking movements, lines and network loads.

In work [34], the real behavior of a passenger is modeled when choosing between variants of travel that combine 
a trip in public transport with a car or a bicycle. The approach for solving the problems of optimizing the intercity passenger bus transportation network based on the development of a regional standard for the quality of services and a system of principles for its design was proposed [35]. In work, the definition of a network is based on the formation of an implemented set of route options with the choice of their optimal combination. The method and indicators of the quality assessment of the route network are proposed.

An evaluation of the performance of public transport systems based on the spatial and temporal properties of the system is presented in [36].

\section{Methods of research}

To establish the scientific approaches proposed by contemporaries on the calculation of passenger correspondence between cities, taking into account their geographical calculation, social and economic indicators, it is suggested to use methods of system analysis for studying contemporary scientific thought on the topic of research. Determine methods for predicting the distribution of correspondence between modes of transport, using mathematical modeling techniques to determine the parameters of the technological process of transporting passengers. Choose methods of field studies to determine the actual parameters of the technological process of transport and mathematical statistics to assess the adequacy of the developed models.

\section{Research results}

Based on the research results, it can be concluded that at present there are scientific approaches to the calculation of passenger correspondence between cities.

Among such approaches one can see the proposed in [37], which is used to predict the passenger flow between different geographical points.

Unknown parameters are estimated using aggregated data, when information is provided only about the number of passengers of each city. The weighted sum of residual areas is used as an effective evaluation criterion.

$$
H_{I i, j}=\frac{\left(H_{m i} H_{m j}\right)^{\theta}}{\left(l_{i, j}\right)^{\tau}} \exp \left(a+\left(c_{(i)}+c_{(j)}\right) P_{g e n}+g_{(i, j)} \gamma_{c}+V_{i, j}\right),
$$

where $H_{I i, j}$ - the number of items in the transport area $i$ in the $j$ area for the calculated period; $a^{H_{H_{i}}}, P_{\text {gen }}^{H_{H_{i}}}=\left(P_{\text {gen } 1}^{H_{H_{i}}} P_{\text {gen } 2}^{H_{H_{i}}} \ldots P_{\text {gen } m}^{H_{H_{i}}}\right)^{T}$ and $\gamma_{c}^{H_{l i}}=\left(\gamma_{c 1}^{H_{l i}} \gamma_{c 2}^{H_{l_{i}}} \ldots \gamma_{c m}^{H_{H_{i}}}\right)^{T}$ - unknown regression parameters; $P_{\text {gen }}$ - general mobility of the population; $\gamma_{c}$ - the coefficient of average use of the cabin capacity; $c_{(i)}=\left(c_{i, j} \ldots c_{i, m}\right)$ and $g_{(I, l)}=\left(c_{i, 1} c_{j, 1} \ldots c_{i, m} c_{j, m}\right)-m-$ data sets; $\left\{V_{i, j}\right\}$ are independent and identically distributed random variables with mean zero and unknown variance; $l_{i, j}$ - distance between areas $i$ and $j ; H_{m i}, H_{m j}$ - the number of inhabitants in $i$ and $j$, respectively.

There are developed models for predicting the annual movement of people from the region to the region. The following dependence was proposed in [38]:

$$
H_{i j}=H_{I i}\left[\frac{H_{a j} F_{r i j} F_{i j}}{\sum_{j} H_{a j} F_{r i j} F_{i j}}\right],
$$

where $H_{i j}$ - the number of trips from $i$ to $j ; H_{I i}-$ the number of items by transport district $i$ for the calculated period; $H_{a j}$ - the number of arrivals to the transport district $j$ for the calculated period; $F_{r i j}$ - transportation resistance factor; $F_{i j}$ - the factor of socio-economic adaptation for the exchange $i j$.

Also, the development of the region's economic development was established for the parameters of passenger correspondence. For this purpose, the authors used [39] to use Newton's gravitational model for this prediction. Based on this model, the authors suggested that the attraction between cities is represented through an adapted model of gravity:

$$
F_{i}=\frac{V V P_{i} \times H_{c i} \times V V P_{j} \times H_{c j}}{\left(l_{r i j} \times T_{a v i j}\right)^{2}},
$$

where $F_{i}$ - the attractiveness factor of the i-th district for expressing the number of potential passengers, possibly came to the city $i$ from city $j ; V V P_{i}, V V P_{j}$ - the gross domestic product of cities and $j$, respectively, in the pair $x$; $H_{c i}, H_{c j}$ - the number of inhabitants in city $i$ and $j$ respectively; $l_{r i j}$ - the length of the route between $i$ and $j$; $T_{a v i j}$ - the average cost of air travel between $i$ and $j$.

To calculate the number of passengers on the arcs of the route network $-Q_{D i j}$, the quantitative approach (3) was adapted to:

$$
Q_{D i j}=\sqrt{\begin{array}{l}
\left(V V P_{i x} \times V V P_{m y}\right)^{2}+\left(V V P_{j x} \times V V P_{m y}\right)^{2}+ \\
+\left(H_{m i x} \times H_{m y}\right)^{2}+\left(H_{m j x} \times H_{m n y}\right)^{2}+ \\
+\left(T_{a z x} \times T_{c a v}\right)^{2}+\left(l_{i j x} \times l_{i j y}\right)^{2} .
\end{array}}
$$

Similar approaches using gravitational modeling are presented in other scientific papers [40-44].

According to the author of the paper [45], in order to determine the distribution of potential passenger correspondence between modes of transport to the place of use of the following relationship:

$$
P_{k}=\frac{e^{U k}}{\sum_{Z} e^{U k}}
$$

where $p_{k}$ - the proportion of trips made in $k$ mode; $U_{k}-$ the utility of the $k$ mode; $\mathrm{Z}$ - efficiency index of all modes; $e-2,718281 \ldots$

\section{SWOT analysis of research results}

Strengths. Among the strengths of this research can be attributed evidence of the possibility of using gravity modeling in the system of long-distance passenger traffic. In favor of this assertion, modern scientific achievements, which are set forth in the literature under review. It is with these circumstances in the practical conditions of using gravity models to calculate the performance of the system is not possible without the prior invention of corrective coefficients. The use of the data obtained with respect to the optimum values of the invented parameters of the values of the attraction function components provides the possibility of calculating the qualitative performance indicators and planning the parameters of the considered transport system. 
Weaknesses. The weakness of the research and obtained results can be determined that at present, scientists have not fully studied the issues of the integrated accounting of the influence of various factors on the indicators of the redistribution of passenger correspondence between modes of transport. Simultaneously, the established methods for determining passenger transport correspondence between the network nodes do not rely on a comprehensive accounting of technical, economic and social indicators.

Opportunities. Accurately calculated value of passenger long-distance transport correspondence on public routes allows to ensure planning of interaction between systems of different modes of transport to meet the needs of the population of the country in meeting the needs of its inhabitants for movement within the investigated system. At the same time, it is possible to improve the quality of the financial flows of production by optimizing the allocation of resources over time throughout the passenger system.

Threats. There are difficulties in applying the research results. This is due to the fact that to apply the selected approaches to the calculation of potential correspondence there is a need to determine the actual values of the calibration coefficients.

\section{Conclusions}

1. Scientific approaches to the calculation of passenger correspondence between cities, which rely on the modeling of transport processes using gravitational modeling techniques, are investigated. Accounting for geographical location of transport nodes, their social and economic characteristics are used as factors of attractiveness or resistance to passenger correspondence. At the same time, at this stage of the development of scientific approaches to the formalization of the parameters of passenger transport correspondence, the integrated accounting of the flow of technical and economic parameters of the carriage for satisfying the demand is determined at an insufficient level.

2. The modern methods for predicting the distribution of correspondence between modes of transport are based on the probability of choosing the mode of transportation from the proposed options. At the same time, the definition of the parameters of such probability is proposed to be implemented from the approach of concrete efficiency of the transportation.

\section{References}

1. Spichkova, M. Formal Model for Intelligent Route Planning [Text] / M. Spichkova, M. Simic, H. Schmidt // Procedia Computer Science. - 2015. - Vol. 60. - P. 1299-1308. doi:10.1016/ j.procs.2015.08.196

2. Deri, A. Efficient Usage of Transfer based System in Intracity Bus Transit Operation: Sample of Izmir [Text] / A. Deri, A. Kalpakci // Procedia - Social and Behavioral Sciences. 2014. - Vol. 111. - P. 311-319. doi:10.1016/j.sbspro.2014.01.064

3. Dib, O. A multimodal transport network model and efficient algorithms for building advanced traveler information systems [Text] / O. Dib, M.-A. Manier, L. Moalic, A. Caminada // Transportation Research Procedia. - 2017. - Vol. 22. - P. 134-143. doi:10.1016/j.trpro.2017.03.020

4. Vissat, L. L. Finding Optimal Timetables for Edinburgh Bus Routes [Text] / L. L. Vissat, A. Clark, S. Gilmore // Electronic Notes in Theoretical Computer Science. - 2015. - Vol. 310. P. 179-199. doi:10.1016/j.entcs.2014.12.018
5. Zhu, W. Generating route choice sets with operation information on metro networks [Text] / W. Zhu, R. Xu // Journal of Traffic and Transportation Engineering (English Edition). Vol. 3, No. 3. - P. 243-252. doi:10.1016/j.jtte.2016.05.001

6. Arhin, S. Optimization of transit total bus stop time models [Text] / S. Arhin, E. Noel, M. F. Anderson, L. Williams, A. Ribisso, R. Stinson // Journal of Traffic and Transportation Engineering (English Edition). - 2016. - Vol. 3, No. 2. P. 146-153. doi:10.1016/j.jtte.2015.07.001

7. Kalaanidhi, S. Estimation of Bus Transport Ridership Accounting Accessibility [Text] / S. Kalaanidhi, K. Gunasekaran // Procedia - Social and Behavioral Sciences. - 2013. - No. 104. P. 885-893. doi:10.1016/j.sbspro.2013.11.183

8. Sun, Y. Joint Optimization of a Rail Transit Route and Bus Routes in a Transit Corridor [Text] / Y. Sun, X. Sun, B. Li, D. Gao // Procedia - Social and Behavioral Sciences. - 2013. Vol. 96. - P. 1218-1226. doi:10.1016/j.sbspro.2013.08.139

9. Menukhova, T. Using of Regionalization Techniques to Select Optimal Routes Based on Criteria of Road Features [Text] / T. Menukhova, A. Vyushkova // Transportation Research Procedia. 2017. - Vol. 22. - P. 436-442. doi:10.1016/j.trpro.2017.01.071

10. Bakas, I. A Flexible Transportation Service for the Optimization of a Fixed-route Public Transport Network [Text] / I. Bakas, R. Drakoulis, N. Floudas, P. Lytrivis, A. Amditis // Transportation Research Procedia. - 2016. - Vol. 14. - P. 1689-1698. doi:10.1016/j.trpro.2016.05.134

11. Youlong, L. Route Optimization Algorithm and Solution for Web Service Engineering [Text] / L. Youlong, N. Guihua // Systems Engineering Procedia. - 2012. - Vol. 5. - P. 427-436. doi:10.1016/j.sepro.2012.04.065

12. Briem, L. Integrating public transport into mobiTopp [Text] / L. Briem, H. S. Buck, N. Mallig, P. Vortisch, B. Strasser, D. Wagner, T. Zundorf // Procedia Computer Science. - 2017. Vol. 109. - P. 855-860. doi:10.1016/j.procs.2017.05.401

13. Aparicio, A. Exploring the Sustainability Challenges of Longdistance Passenger Trends in Europe [Text] / A. Aparicio // Transportation Research Procedia. - 2016. - Vol. 13. - P. 90-99. doi:10.1016/j.trpro.2016.05.010

14. Bohari, Z. Improving the Quality of Public Transportation System: Application of Simulation Model for Passenger Movement [Text] / Z. A. Bohari, S. Bachok, M. M. Osman // Procedia - Social and Behavioral Sciences. - 2014. - Vol. 15. P. 542-552. doi:10.1016/j.sbspro.2014.10.087

15. Haar, S. A Hybrid-Dynamical Model for Passenger-flow in Transportation Systems**This research work has been carried out under the leadership of the Technological Research Institute SystemX, and therefore granted with public funds within the scope of the French Program «Investissements d'Avenir» [Text] / S. Haar, S. Theissing // IFAC-PapersOnLine. - 2015. - Vol. 48, No. 27. - P. 236-241. doi:10.1016/j.ifacol.2015.11.181

16. Sun, D. Timetable optimization for single bus line based on hybrid vehicle size model [Text] / D. Sun, Y. Xu, Z.-R. Peng // Journal of Traffic and Transportation Engineering (English Edition). - 2015. - Vol. 2, No. 3. - P. 179-186. doi:10.1016/ j.jtte.2015.03.006

17. Vrtic, M. Two-dimensionally constrained disaggregate trip generation, distribution and mode choice model: Theory and application for a Swiss national model [Text] / M. Vrtic, P. Frohlich, N. Schussler, K. W. Axhausen, D. Lohse, C. Schiller, H. Teichert // Transportation Research Part A: Policy and Practice. - 2007. Vol. 41, No. 9. - P. 857-873. doi:10.1016/j.tra.2006.10.003

18. Rwakarehe, E. E. Development of a Freight Demand Model for the Province of Alberta Using Public Sources of Data [Text] / E. E. Rwakarehe, M. Zhong, J. Christie // Procedia - Social and Behavioral Sciences. - 2014. - Vol. 138. - P. 695-705. doi:10.1016/j.sbspro.2014.07.263 
19. Fornalchyk, Ye. The Model of Correspondence of Passenger Transportation on the Basis of Fuzzy Logic [Text] / Ye. Fornalchyk, A. Bilous, I. Demchuk // Econtechmod. An International Quarterly Journal. - 2015. - Vol. 4, No. 2. - P. 59-64.

20. Grosche, T. Gravity models for airline passenger volume estimation [Text] / T. Grosche, F. Rothlauf, A. Heinzl // Journal of Air Transport Management. - 2007. - Vol. 13, No. 4. P. 175-183. doi:10.1016/j.jairtraman.2007.02.001

21. $\mathrm{Wu}, \mathrm{C}$. The impact of route network expansion on airport attractiveness: a case study of Chubu international airport in Japan [Text] / C. Wu, J. Han, Y. Hayashi // Proceedings of the 2011 World Conference of Air Transport Research Society. - 2011. - P. 1-14.

22. Moreno, E. G. A First Step to Diagnostic of Urban Transport Operations by Means of GPS Receiver [Text] / E. G. Moreno, M. G. Romana, O. Martinez // Procedia Computer Science. 2016. - Vol. 83. - P. 305-312. doi:10.1016/j.procs.2016.04.130

23. Hu, Y. A Model Layout Region Optimization for Feeder Buses of Rail Transit [Text] / Y. Hu, Q. Zhang, W. Wang // Procedia - Social and Behavioral Sciences. - 2012. - Vol. 43. P. 773-780. doi:10.1016/j.sbspro.2012.04.151

24. Fonzone, A. A Model of Bus Bunching under Reliability-based Passenger Arrival Patterns [Text] / A. Fonzone, J.-D. Schmocker, R. Liu // Transportation Research Procedia. - 2015. - Vol. 7. P. 276-299. doi:10.1016/j.trpro.2015.06.015

25. Raturi, V. Analyzing Inter-modal Competition between High Speed Rail and Conventional Transport Systems: A Game Theoretic Approach [Text] / V. Raturi, K. Srinivasan, G. Narulkar, A. Chandrashekharaiah, A. Gupta // Procedia - Social and Behavioral Sciences. - 2013. - Vol. 104. - P. 904-913. doi:10.1016/ j.sbspro.2013.11.185

26. Tuaycharoen, N. Bangkok Bus Route Planning API [Text] / N. Tuaycharoen, A. Sakcharoen, W. Cha-aim // Procedia Computer Science. - 2016. - Vol. 86. - P. 441-444. doi:10.1016/ j.procs.2016.05.075

27. Zhang, C. Bus Dwell Time Estimation and Prediction: A Study Case in Shanghai-China [Text] / C. Zhang, J. Teng // Procedia - Social and Behavioral Sciences. - 2013. - Vol. 96. P. 1329-1340. doi:10.1016/j.sbspro.2013.08.15

28. Oazi, A.-N. Demand variations and evacuation route flexibility in short-notice bus-based evacuation planning [Text] / A.-N. Oazi, Y. Nara, K. Okubo, H. Kubota // IATSS Research. Elsevier BV, 2017. doi:10.1016/j.iatssr.2017.01.002

29. Zhang, X. Modeling the Effects of Low-carbon Emission Constraints on Mode and Route Choices in Transportation Networks [Text] / X. Zhang, P. Liu, Z. Li, H. Yu // Procedia - Social and Behavioral Sciences. - 2013. - Vol. 96. - P. 329-338 doi:10.1016/j.sbspro.2013.08.040

30. Dave, S. M. Modeling Trip Attributes and Feasibility Study of co-ordinated Bus for School Trips of Children [Text] S. M. Dave, D. P. Raykundaliya, S. N. Shah // Procedia - Socia and Behavioral Sciences. - 2013. - Vol. 104. - P. 650-659. doi:10.1016/j.sbspro.2013.11.159

31. Richter, C. Modelling Mode Choice in Passenger Transport with Integrated Hierarchical Information Integration [Text] C. Richter, S. Keuchel // Journal of Choice Modelling. - 2012. Vol. 5, No. 1. - P. 1-21. doi:10.1016/s1755-5345(13)70045-9

32. Kabashkin, I. Modelling of Regional Transit Multimodal Transport Accessibility with Petri Net Simulation [Text] / I. Kabashkin // Procedia Computer Science. - 2015. - Vol. 77. P. 151-157. doi:10.1016/j.procs.2015.12.373

33. Essadeq, I. Modelling Passenger Congestion in Transit System - Benchmark and Three Case Studies [Text] / I. Essadeq, E. Dubail, E. Jeanniere // Transportation Research Procedia. - 2016. - Vol. 14. - P. 1792-1801. doi:10.1016/ j.trpro.2016.05.145

34. Brands, T. Modelling public transport route choice, with multiple access and egress modes [Text] / T. Brands, E. de Romph, T. Veitch, J. Cook // Transportation Research Procedia. - 2014. Vol. 1, No. 1. - P. 12-23. doi:10.1016/j.trpro.2014.07.003

35. Panasyuk, M. V. Optimization of regional passenger bus traffic network [Text] / M. V. Panasyuk, E. M. Pudovik, M. E. Sabirova // Procedia Economics and Finance. - 2013. - Vol. 5. P. 589-596. doi:10.1016/s2212-5671(13)00069-5
36. Hadas, Y. Public Transport Systems' Connectivity: Spatiotemporal Analysis and Failure Detection [Text] / Y. Hadas, R. Rossi, M. Gastaldi, G. Gecchele // Journal of Transportation Research Procedia. - 2014. - Vol. 3. - P. 309-318. doi:10.1016/ j.trpro.2014.10.011

37. Baik, H. Forecasting Model for Air Taxi, Commercial Airline, and Automobile Demand in the United States [Text] H. Baik, A. Trani, N. Hinze, H. Swingle, S. Ashiabor, A. Seshadri // Transportation Research Record: Journal of the Transportation Research Board. - 2008. - Vol. 2052. - P. 9-20. doi:10.3141/2052-02

38. Terekhov, I. A concept of forecasting origin-destination air passenger demand between global city pairs using future socio-economic scenarios [Text] / I. Terekhov, V. Gollnick // 53rd AIAA Aerospace Sciences Meeting. - American Institute of Aeronautics and Astronautics, 2015. - P. 1640. doi:10.2514/6.2015-1640

39. Dolya, C. Modeling of passenger transport correspondence between regional centers in Ukraine [Text] / C. Dolya // Technology Audit and Production. - 2017. - Vol. 1, No. 2 (33). P. 44-48. doi:10.15587/2312-8372.2017.93458

40. Dolya, C. Modeling of intercity passenger transportation system [Text] / C. Dolya // Technology Audit and Production Reserves. - 2017. - Vol. 2, No. 2 (34). - P. 37-43. doi:10.15587/23128372.2017.100465

41. Xiao-qiang, L. The Passenger Demand Prediction for Airport Line of Rail Traffic [Text] / L. Xiao-qiang, W. Lei // Metallurgical and Mining Industry. -2015. - No. 9. - P. 651-657.

42. Mao, L. Modeling monthly flows of global air travel passengers: An open-access data resource [Text] / L. Mao, X. Wu, Z. Huang, A. J. Tatem // Journal of Transport Geography. 2015. - Vol. 48. - P. 52-60. doi:10.1016/j.jtrangeo.2015.08.017

43. Park, M. Regional Freight Demand Estimation Using Korean Commodity Flow Survey Data [Text] / M. Park, J. Hahn // Journal of Transportation Research Procedia. - 2015. - Vol. 11. P. 504-514. doi:10.1016/j.trpro.2015.12.042

44. Schwieterman, J. Intercity Buses: 2015 Was A Smooth Ride [Electronic resource] / J. Schwieterman // New Geography. 02.10.2016. - Available at: \www/URL: http://www.newgeography.com/content/005157-intercity-buses-2015-was-a-smooth-ride

45. Li, T. A Demand Estimator Based on a Nested Logit Model [Text] / T. Li // Transportation Science. - 2017. - Vol. 51, No. 3. - P. 918-930. doi:10.1287/trsc.2016.0671

\section{ИССЛЕДОВАНИЕ ПОДХОДОВ К МОДЕЛИРОВАНИЮ СИСТЕМЫ МЕЖДУГОРОДНИХ ПАССАЖИРСКИХ ЛЕРЕВОЗОК}

Исследовано состояние современных научных подходов к прогнозированию параметров междугородних пассажирских корреспонденций. Установлено, что междугородние пассажирские транспортные корреспонденции можно рассчитать, используя современные подходы, основанные на принципе гравитациного моделирования. В системе междугородних пассажирских маршрутных перевозок наблюдаются процессы распределения пассажиропотока между видами транспорта благодаря набору вариантов реализаций потребности пассажиров на передвижение.

Ключевые слова: транспортная система, гравитационная модель, пассажирские транспортные корреспонденции, междугородние перевозки

Dolya Constantine, PhD, Senior Lecturer, Department of GIS, Land and Real Estate Appraisal, O. M. Beketov National University of Urban Economy in Kharkiv, Ukraine, e-mail: c.dolya@ukr.net, ORCID: http://orcid.org/0000-0002-4693-9158

Botsman Anastasiia, Department of Transport System and Logistics, O. M. Beketov National University of Urban Economy in Kharkiv, Ukraine, e-mail: botsman.nastya@gmail.com, ORCID: http://orcid.org/ 0000-0002-0308-0339

Kozhyna Viktoriia, Department of Transport System and Logistics, O. M. Beketov National University of Urban Economy in Kharkiv, Ukraine, e-mail: kozhina.viktoria@gmail.com, ORCID: http://orcid.org/ 0000-0003-0923-3663 